\title{
Sarcomatoid Squamous Cell Carcinoma of the Conjunctiva: A Rare Entity and A Brief Review of Literature
}

\author{
Sahil Agrawal ${ }^{1}$, Sujeeth Modaboyina ${ }^{1}$, Seema Sen ${ }^{2}$, Suman Kumari Meena ${ }^{1}$, \\ Saloni Gupta ${ }^{3}$ and Deepsekhar Das ${ }^{1 *}$ \\ 'Dr. Rajendra Prasad Centre for Ophthalmic Sciences, All India Institute of Medical Sciences, New Delhi -110 029, India \\ ${ }^{2}$ Department of Ocular Pathology, Dr. Rajendra Prasad Centre for Ophthalmic Sciences, All India Institute of \\ Medical Sciences, New Delhi -110 029, India \\ ${ }^{3}$ Northern Railway Central Hospital, Connaught Place, New Delhi -110 029, India
}

\begin{abstract}
Sacrcomatoid variant of squamous cell carcinoma has been known to involve numerous tissues like an aerodigestive tract, skin. A reddish mass of the left bulbar conjunctiva, with intraocular extension on ultra-bio-microscopy (UBM) was present. Histopathologic examination showed the characteristic spindle-shaped cells in continuity with the overlying epithelium with positive immunostains for cytokeratin, epithelial membrane antigen and vimentin. The presence of such an entity in the conjunctiva is rare and here we report such a case, this being the 37 th case to be documented in literature. We also give a brief review of literature.
\end{abstract}

Keywords: Sarcomatoid Squamous Cell Carcinoma, Spindle Cell Carcinoma, OSSN, Ocular Surface Tumor, Enucleation

\section{Introduction}

Ocular surface squamous cell neoplasia is the most common carcinoma of the ocular surface. The spindle cell (sarcomatoid variant) of squamous cell carcinoma of the conjunctiva is a rare variant of squamous cell carcinoma which is more aggressive; typically, they are vimentinpositive and weak staining for cytokeratin and EMA. An epithelial origin with dedifferentiation to a spindle cell morphology is the most accepted hypothesis. The cells shift from a squamoid to spindled appearance due to dysfunctional intercellular adhesion complex, causing more infiltration ${ }^{[1]}$. The tumour, due to its aggressive nature, has a higher likelihood of intraocular extension. It needs to be identified and properly removed. Here we describe the 37th such case ever documented and a brief review of the literature.

\section{Case Description}

A 40-year-old male presented with a complaint of a pinkish mass in his left eye for three months. The lesion started as a small swelling in the superomedial part of the bulbar conjunctiva and gradually increased in size over three months to encroach the medial aspect of the left eye. He had no history of trauma, smoking or any other addiction or any mass anywhere else in the body. He had no history of any systemic illness.

On general examination, he was well built, and there was no evidence of any systemic illness. On local ophthalmological examination, he had a visual acuity of
6/9 in both eyes, and intraocular pressure was $16 \mathrm{~mm} \mathrm{Hg}$. Anterior and posterior segment examination of the right eye was within normal limits. On viewing his left eye, his left eyelids were edematous. Local examination showed a gelatinous, reddish mass which was soft and lobulated on palpation. It extended from medial canthus medially and engulfed medial half of cornea from 6 o'clock to 1 o'clock. (Figure 1). Superiorly and inferiorly, it extended up to the fornices. A prominent tortuous vessel which ran diagonally from above downwards towards the cornea fed the tumour mass. Slit-lamp examination of the anterior segment was within normal limit except for senile cataractous changes. Posterior segment examination was within normal limits. Extraocular movements were full and within normal limits.

An ultrasound bio-microscopy showed corneal and anterior segment involvement with sparing of the ciliary body. A contrast-enhanced computed tomography (CECT) scan ruled out an orbital extension.

Based on the clinical findings and history, a diagnosis of left eye ocular surface squamous cell neoplasia was made. The patient underwent USG of the cervical nodes and abdomen to rule out any systemic spread of the disease, which came out to be negative. As per AJCC 8th edition, the clinical stage of tumour was T3N0M0.

The patient underwent extended enucleation followed by cryotherapy of the margins of conjunctiva followed by a primary silicone implant placement. The enucleated 
specimen was sent for histopathological examination, which showed a tumour measuring $12 \mathrm{~mm}$ at the limbus. The tumour cells were spindle-shaped and infiltrated the corneal stroma, sclera, and trabecular meshwork. Focal squamoid differentiation was seen (Fig 2 A-C). On IHC these were positive for pancytokeratin (AE1/AE3), epithelial membrane antigen, p63 and vimentin (Figure 3 A\&B). Immunostains were negative for S-100, desmin, SMA, CD 34 and HMB-45. Thus, a diagnosis of spindle cell variant of squamous cell carcinoma was reached. The patient has been on follow up for three months, and there has been no evidence of any recurrence to date.

Table 1: Review of cases of sarcomatoid squamous cell carcinoma of the conjunctiva.

\begin{tabular}{|c|c|c|c|c|c|c|c|}
\hline $\begin{array}{l}\text { S. } \\
\text { No }\end{array}$ & Study & $\begin{array}{l}\text { Age at presentation } \\
\text { /gender }\end{array}$ & $\begin{array}{l}\text { Clinical } \\
\text { Presentation }\end{array}$ & Treatment & Histopathology features & $\mathrm{IHC}$ & Outcome \\
\hline \multirow[t]{2}{*}{1.} & \multirow[t]{2}{*}{ Cohen et al., 1980 [5] } & Case $1-28$ y /M & $\begin{array}{l}\text { Inferotemporal } \\
\text { subconjunctival mass }\end{array}$ & $\begin{array}{l}\text { Conjunctival } \\
\text { Excisional biopsy }\end{array}$ & $\begin{array}{l}\text { Continuity of tumor with surface } \\
\text { epithelium no surface atypia } \\
\text { (misdiagnosed as chronic } \\
\text { inflammation and malignant } \\
\text { fibrous histiocytoma) }\end{array}$ & Not available & $\begin{array}{l}\text { Recurrence and resections } \\
\text { ( } 2 \text { times). Exenteration } \\
\text { - no recurrence and } \\
\text { metastasis in } 9 \text { months } \\
\text { follow up. }\end{array}$ \\
\hline & & Case $2-30$ y / M & $\begin{array}{l}\text { Vascular mass in nasal } \\
\text { limbus }\end{array}$ & Excisional biopsy & $\begin{array}{l}\text { Stromal infiltration by atypical } \\
\text { spindle cells continuous with } \\
\text { surface epithelium }\end{array}$ & Not available & Not available \\
\hline \multirow[t]{6}{*}{2.} & \multirow{6}{*}{$\begin{array}{l}\text { Huntington et al } \\
1990 \text { (retrospective } \\
\text { study of } 6 \text { cases } \\
\text { registered in AFIP) } \\
\text { Intraocular extension } \\
\text { present in all } 6 \text { cases } \\
\text { EMA present in all } 6 \\
\text { cases [7] }\end{array}$} & Case $1-30$ y / F & Not known & Exenteration & \multirow{6}{*}{$\begin{array}{l}\text { Stromal tissue infiltrated by } \\
\text { chronic inflammatory cells, } \\
\text { spindle shaped tumor cells } \\
\text { present. } 4 \text { out of } 6 \text { cases showed } \\
\text { continuity with overlying surface } \\
\text { epithelium. }\end{array}$} & $\begin{array}{l}\text { Polyclonal anti keratin + } \\
\text { Anti - EMA + } \\
\text { AE1/3 - } \\
\text { PKK1 - }\end{array}$ & \multirow[t]{6}{*}{ Not studied } \\
\hline & & Case 2 - 72 y/M & $\begin{array}{l}\text { Phthisical eye with Limbal } \\
\text { papilloma (past history } \\
\text { of recurrent keratitis and } \\
\text { underwent multiple ocular } \\
\text { surgeries) }\end{array}$ & \multirow[t]{3}{*}{ Enucleation } & & $\begin{array}{l}\text { Polyclonal anti keratin + } \\
\text { Anti - EMA - } \\
\text { AE1/3 + } \\
\text { PKK1 + }\end{array}$ & \\
\hline & & Case $3-55$ y $/ \mathrm{M}$ & $\begin{array}{l}\text { Phthisical eye with } \\
\text { multiple conjunctival } \\
\text { nodules and unspecified } \\
\text { ocular inflammation for } \\
40 \text { years }\end{array}$ & & & $\begin{array}{l}\text { Polyclonal anti keratin + } \\
\text { Anti - EMA + } \\
\text { AE1/3- } \\
\text { PKK1 + }\end{array}$ & \\
\hline & & Case 4 -85y/M & $\begin{array}{l}\text { Large, Solitary, sessile } \\
\text { limbal mass overlying } \\
\text { cornea }\end{array}$ & & & $\begin{array}{l}\text { Polyclonal anti keratin + } \\
\text { Anti - EMA- } \\
\text { AE1/3 - } \\
\text { PKK1 - }\end{array}$ & \\
\hline & & Case $5-80 y / F$ & $\begin{array}{l}\text { Single nodule of bulbar } \\
\text { conjunctiva }\end{array}$ & Exenteration & & $\begin{array}{l}\text { Polyclonal anti keratin - } \\
\text { Anti - EMA - } \\
\text { AE1/3 - } \\
\text { PKK1 - }\end{array}$ & \\
\hline & & Case 6 - & $\begin{array}{l}\text { Single nodule of bulbar } \\
\text { conjunctiva }\end{array}$ & Excisional biopsy & & $\begin{array}{l}\text { Polyclonal anti keratin - } \\
\text { Anti - EMA - } \\
\text { AE1/3 - } \\
\text { PKK1 - }\end{array}$ & \\
\hline 3. & $\begin{array}{l}\text { Schubert et al., } \\
\text { 1995[8] }\end{array}$ & $31 y / F$ & $\begin{array}{l}2.5 \mathrm{~mm} \text { bulbar } \\
\text { conjunctival mass }\end{array}$ & Excisional biopsy & $\begin{array}{l}\text { Spindle shaped cells continuous } \\
\text { with surface epithelium. } \\
\text { with presence of chronic } \\
\text { inflammation }\end{array}$ & $\begin{array}{l}\text { Cytokeratin + } \\
\text { EMA antigen positive }\end{array}$ & $\begin{array}{l}\text { No recurrence in 5-year } \\
\text { lamellar resection of sclera } \\
\text { at original site of nodule } \\
\text { with cryotherapy }\end{array}$ \\
\hline 4. & $\begin{array}{l}\text { Seregard et al., } \\
\text { 1995[9] }\end{array}$ & $70 \mathrm{y} / \mathrm{M}$ & Pterygium & Excisional biopsy & $\begin{array}{l}\text { Spindle cells infiltrating } \\
\text { stroma diffusely with few } \\
\text { cells continuous with surface } \\
\text { epithelium above }\end{array}$ & $\begin{array}{l}\text { Vimentin }+ \\
\text { Monoclonal antibodies for } \\
\text { MFN 116+ } \\
\text { AE } 1 / 3 \text { - }\end{array}$ & $\begin{array}{l}\text { Recurrence (2 times) } \\
\text { Received EBRT } \\
\text { Metastasis to lung and ribs } \\
\text { Died in } 14 \text { months after } \\
\text { initial treatment }\end{array}$ \\
\hline 5. & $\begin{array}{l}\text { Slushker et al., } \\
1997[10]\end{array}$ & $101 \mathrm{Y} / \mathrm{F}$ & $\begin{array}{l}\text { Large mass arising from } \\
\text { conjunctiva }\end{array}$ & Enucleation & $\begin{array}{l}\text { Spindle shaped cells with } \\
\text { pleomorphism }\end{array}$ & $\begin{array}{l}\text { EMA + } \\
\text { Cytokeratin + } \\
\text { Vimentin - } \\
\text { S100 - } \\
\text { HMB 45 - }\end{array}$ & Not reported \\
\hline 6. & $\begin{array}{l}\text { Shields et al., } \\
\text { 2007[11] }\end{array}$ & $51 \mathrm{Y} / \mathrm{M}$ & Pterygium & Excision & $\begin{array}{l}\text { Spindle cells subepithelial and } \\
\text { CD } 68 \text { positive multinucleated } \\
\text { giant cells }\end{array}$ & $\begin{array}{l}\text { Vimentin + } \\
\text { S100 - } \\
\text { HMB 45 - } \\
\text { AE1/AE 3 - }\end{array}$ & $\begin{array}{l}\text { Recurrence in } 1 \text { month } \\
\text { - full thickness eye wall } \\
\text { resection with scleral graft } \\
\text { No tumor recurrence in } 6 \\
\text { months }\end{array}$ \\
\hline
\end{tabular}




\begin{tabular}{|c|c|c|c|c|c|c|c|}
\hline $\begin{array}{l}\text { S. } \\
\text { No }\end{array}$ & Study & $\begin{array}{l}\text { Age at presentation } \\
\text { /gender }\end{array}$ & $\begin{array}{l}\text { Clinical } \\
\text { Presentation }\end{array}$ & Treatment & Histopathology features & $\mathrm{IHC}$ & Outcome \\
\hline 7. & $\begin{array}{l}\text { H.M.Alkatan et al., } \\
\text { 2010[12] }\end{array}$ & $72 y / M$ & $\begin{array}{l}\text { Recurrent lesion at site of } \\
\text { previously excised mass } \\
\text { and diagnosed as spindle } \\
\text { cell carcinoma }\end{array}$ & Excision & $\begin{array}{l}\text { misdiagnosed as recurrent } \\
\text { squamous cell carcinoma } \\
\text { (review of slides and report } \\
\text { from exenterated tissue) } \\
\text { showed poorly differentiated, } \\
\text { pleomorphic squamous cells } \\
\text { and continuous with overlying } \\
\text { epithelium }\end{array}$ & Positive for cytokeratin & $\begin{array}{l}\text { Reported } 2 \text { years later } \\
\text { with recurrence for which } \\
\text { anterior exenteration was } \\
\text { done } \\
\text { Bilateral lung metastasis } 3 \\
\text { years after exenteration }\end{array}$ \\
\hline 8. & $\begin{array}{l}\text { Coban et al., } \\
2016[14]\end{array}$ & $85 \mathrm{y} / \mathrm{M}$ & $\begin{array}{l}\text { Pedunculated mass } \\
\text { without ulceration for } 3 \\
\text { months }\end{array}$ & Excisional biopsy & $\begin{array}{l}\text { Carcinoma in situ - spindle or } \\
\text { epithelioid cells arranged in } \\
\text { herds and bundles with presence } \\
\text { inflammatory cells }\end{array}$ & $\begin{array}{l}\text { Vimentin + } \\
\text { Pancytokeratin + } \\
\text { EMA + } \\
\text { SMA + } \\
\text { CD 99, p63, Calponin + ve } \\
\text { Caldesmon and MyoD1 } \\
\text { negative }\end{array}$ & Lost to follow up \\
\hline 9. & Patel et al., 2016 [15] & $55 \mathrm{y} / \mathrm{M}$ & $\begin{array}{l}\text { Pedunculated mass } \\
\text { of conjunctiva without } \\
\text { ulceration for } 4 \text { months }\end{array}$ & Enucleation & $\begin{array}{l}\text { Dysplasia of stroma with spindle } \\
\text { cells arranged in fascicles }\end{array}$ & $\begin{array}{l}\text { AE } 1+ \\
\text { Cytokeratin } 5 / 6+ \\
\text { Vimentin }+ \\
S-100 \text { and HMB } 45 \text { negative }\end{array}$ & Not reported \\
\hline
\end{tabular}

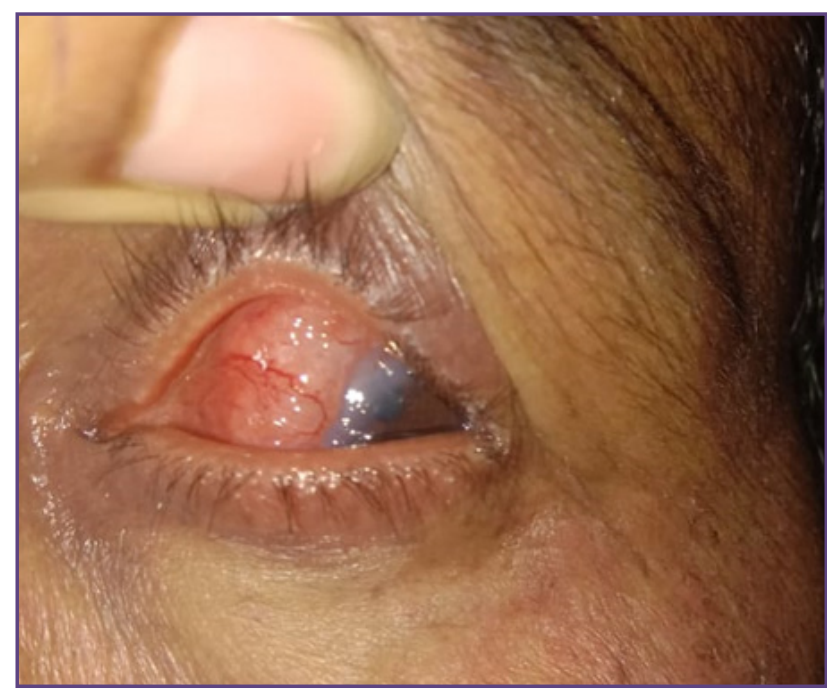

Fig. 1: Clinical picture of the patient showing vascularized fleshy mass in the superomedial aspect of left bulbar conjunctiva with a feeder vessel.

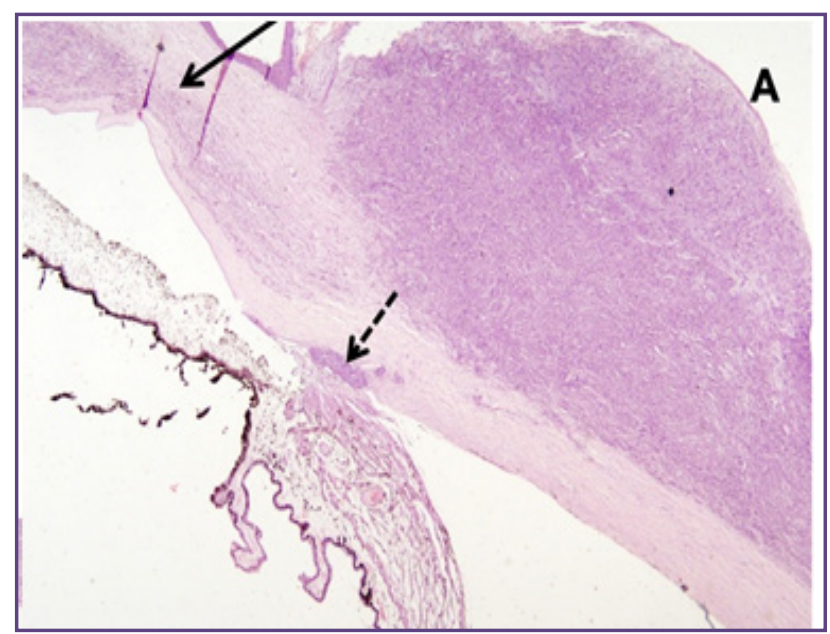

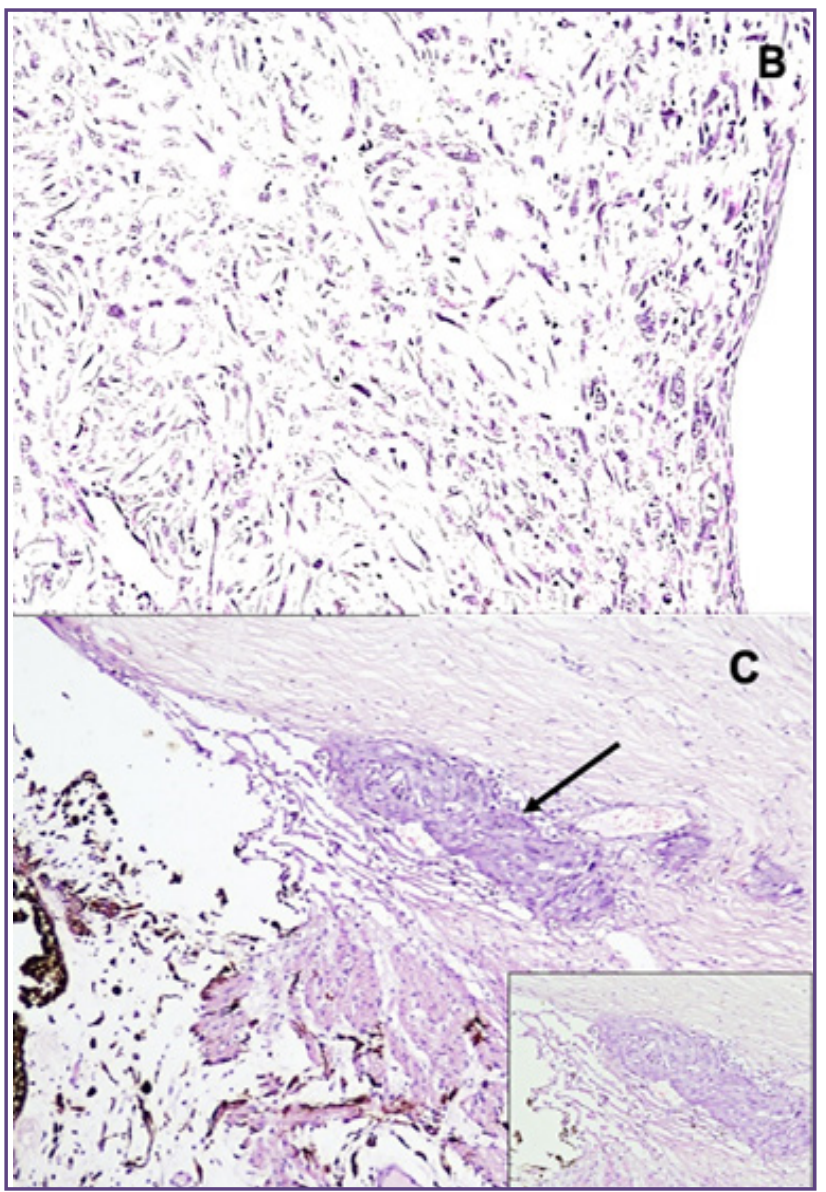

Fig. 2: A- Low power view shows tumor cells in the stroma, scleral infiltration(arrow) and trabecular meshwork infiltration(dashed arrow) is seen (H \&Ex100), B- High power view to show pleomorphic spindle shaped tumor cells below the epithelium(H\&E x200), C- Tumor cells infiltrating the Trabecular meshwork (H\&Ex100, inset shows squamoid appearance of tumor cells (H\&E x 200). 


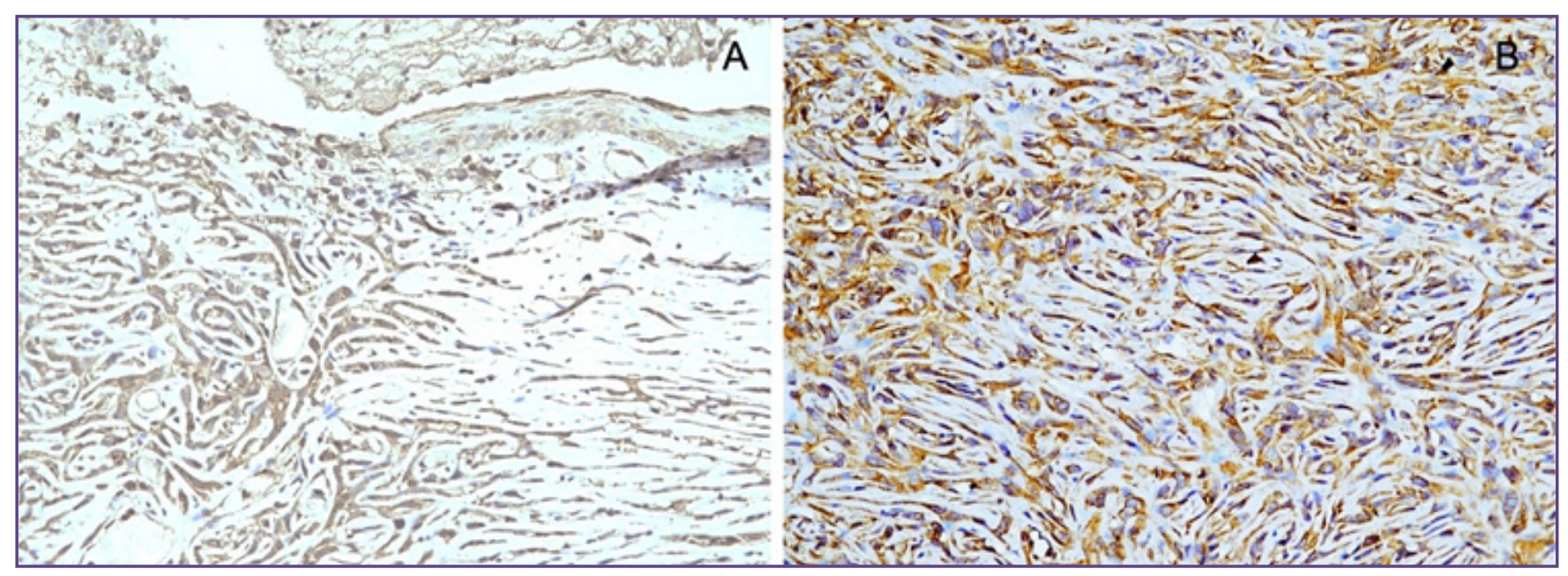

Fig. 3: A- Tumor cells in the subepithelum showing Epithelial membrane positivity(Avidin Biotin x 200), B- Cytoplasmic Vimentin positivity is seen in the tumor cells (Avidin Biotin x 200).

\section{Discussion}

Squamous cell carcinoma is the most common malignant tumour of the conjunctiva ${ }^{[2]}$. It was first described in 1860 by von Graefe ${ }^{[3]}$. Over the period of time, multiple studies have been conducted, which has led to the classification of the disease in many ways. Spindle cell squamous cell carcinoma is a rare and a poorly differentiated variant of squamous cell carcinoma and has been reported to occur in numerous sites like an aerodigestive tract, skin. It is also known as spindle cell carcinoma ${ }^{[3-11]}$. Other terms which have been used to describe the same include polypoid carcinoma, pleomorphic carcinoma, carcinosarcoma or pseudosarcoma ${ }^{[4]}$.

Sarcomatoid or spindle cell carcinoma of the conjunctiva, however, is a very uncommon entity. It arises from squamous cell carcinoma with dedifferentiation to sarcomatoid variant; thus, it comprises two components - epithelial component and mesenchymal component, and so is a biphasic tumour ${ }^{[6]}$. The squamous component may be scant or not seen on light microscopy. In such cases, immunohistochemical evidence of squamous origin is necessary for diagnosis. The sarcomatous component is vimentin-positive with weak staining for cytokeratin/EMA. p63 and p40 are both useful markers with comparable sensitivity for epithelial differentiation in such cases, however p40 has greater specificity ${ }^{[12]}$. Histological feature to guide Immunohistochemistry (IHC) for sarcomatoid squamous cell carcinoma is the presence of spindle cell tumour, which may have continuity with surface epithelium.

On the literature review, the first case of spindle cell carcinoma of the conjunctiva was reported nearly 50 years back by Wise AC in $1967^{[7]}$. Over the past 50 years, a total of 26 cases of spindle cell carcinoma of conjunctiva have been reported. Table 1 gives details of reported cases and outcomes. Other than these cases, in 1997, Cervantes et al. had published a study on clinicopathological features of 287 cases of squamous cell carcinoma of the conjunctiva, of which only 2 were spindle cell carcinoma ${ }^{[16]}$. Ni C and Guo BK studied clinicopathological features of 8 patients and classified spindle cell carcinoma as fibrosarcomatous, rhabdomyosarcomatous and fibrohistiocytomatous ${ }^{[17]}$.

Review of literature suggests sarcomatoid squamous cell carcinoma to be a locally aggressive carcinoma with a risk of recurrence and metastasis if not resected adequately and promptly. Intraocular invasion is common ${ }^{[13]}$. Invasion of the trabecular meshwork has been described in $2 / 26$ conjunctival SCC by Mckelvie et al. None of the 2 cases were, however, sarcomatoid SCC ${ }^{[18]}$.

\section{Conclusion}

Because of its variable and benign appearance, clinician may take a conservative approach initially. It is also challenging for pathologists to give a definitive diagnosis based on histopathological features alone, and it may be misdiagnosed for chronic inflammation or sarcoma. Immunohistochemistry plays a key role in the diagnosis of spindle cell carcinoma where it is positive for cytokeratins, epithelial membrane antigen suggesting epithelial origin with a sarcomatous component. Absence of S-100 and HMB 45 positivity further rules out sarcomatous tumours of neural origin and amelanotic melanoma.

\section{Conflicts of Interest}

None

\section{Sources of Funding}

None 


\section{Acknowledgement}

None

\section{Declaration of Patient Consent}

The authors certify that they have obtained all appropriate patient consent forms. In the form, patient has given his consent for the images and other clinical information to be reported in the journal. The patient understands that his name and initials will not be published, and due efforts will be made to conceal the identity of the patient.

\section{References}

1. Sarma A, Das R, Sharma JD, Kataki AC. Spindle cell carcinoma of the head and neck: a clinicopathological and immunohistochemical study of 40 cases. Journal of Cancer Therapy. 2012; 3:1055-59.

2. Tabbara KF, Kersten R, Daouk N et al. Metastatic squamous cell carcinoma of the conjunctiva. Ophthalmology 1988; 95:318-21.

3. Lee GA, Hirst L W. Ocular surface squamous neoplasia. Surv Ophthalmol 1995; 39:429-50.

4. Shah BJ, Tupkari JV, Joy T. Sarcomatoid squamous cell carcinoma of mandible: A report of two cases. J Oral Maxillofac Pathol 2019; 23:163.

5. Cohen BH, Green WR, Iliff NT et al. Spindle cell carcinoma of the conjunctiva. Arch Ophthalmol 1980; 98:1809-13.

6. Viswanathan S1, Rahman K, Pallavi S et al. Sarcomatoid (spindle cell) carcinoma of the head and neck mucosal region: a clinicopathologic review of 103 cases from a tertiary referral cancer centre.Head Neck Pathol. 2010 Dec;4(4):265-75.

7. Huntington AC, Langloss JM, Hidayat AA. Spindle cell carcinoma of the conjunctiva. An immunohistochemical and ultrastructural study of six cases. Ophthalmology 1990; 97:711-7.

8. Schubert HD, Farris RL, Green WR. Spindle cell carcinoma of the conjunctiva. Graefes Arch Clin Exp Ophthalmol $1995 ; 233: 52-3$.

9. Seregard S1, Kock E. Squamous spindle cell carcinoma of the conjunctiva. Fatal outcome of a plerygium-like lesion. Acta Ophthalmol Scand. 1995 Oct;73(5):464-6.

10. Slusker-Shternfeld I, Syed NA, Sires BA. Invasive spindle cell carcinoma of the conjunctiva. Arch Ophthalmol 1997; 115:288-9.

11. Shields JA1, Eagle RC, Marr BP et al. Invasive spindle cell carcinoma of the conjunctiva managed by full-thickness eye wall resection. Cornea. 2007 Sep;26(8):1014-6.

12. Alkatan HM, Al-Motlak MA, Al-Shedoukhy AA. Metastatic Squamous Spindle Cell Carcinoma of the conjunctiva.Saudi J Ophthalmol. 2010 Oct;24(4):155-8.

13. R Mittal, S Rath, GK Vemuganti. Ocular surface squamous neoplasia-Review of etio-pathogenesis and an update on clinico-pathological diagnosi. Saudi Journal of Ophthalmology. 2013; 27, (3)177-186

14. Coban-Karatas M, Bal N, Altan-Yaycioglu R et al. Spindle cell carcinoma of the conjunctiva: A rare entity. Indian $\mathrm{J}$ Ophthalmol. 2016;64(5):402-404.

15. Mehulkumar K. Patel, Sanjay V. Dhotre, Mahesh B. Patel et al. Case report of spindle cell carcinoma of the conjunctivaa rare tumour International Journal of Current Research and Review. Dec 2016; 8(24):51-53

16. Cervantes G, Rodríguez AA Jr., Leal AG. Squamous cell carcinoma of the conjunctiva: Clinicopathological features in 287 cases. Can J Ophthalmol 2002; 37:14-9.

17. Ni C1, Guo BK. Histological types of spindle cell carcinoma of the cornea and conjunctiva. A clinicopathologic report of 8 patients with ultrastructural and immunohistochemical findings in three tumors.Chin Med J (Engl). 1990 Nov;103(11):915-20.

18. Penelope A McKelvie, Mark Daniell, Alan McNab et al. Squamous cell carcinoma of the conjunctiva: a series of 26 cases. Br J Ophthalmol. 2002; 86(2): 168-173.

*Corresponding author:

Dr. Deepsekhar Das, Oculoplasty and Orbital Tumor Services, Dr. Rajendra Prasad Centre for Ophthalmic Sciences, All India Institute of Medical Sciences, New Delhi -110 029, India

Phone: +91 8375047749

Email: doc.deep.das@gmail.com

Date of Submission : 18/04/2021

Date of Final Revision : 03/06/2021

Financial or other Competing Interests: None. 